\title{
HEAVY METAL AND METALLOID CONCENTRATION DYNAMICS IN MINE AND SURFACE WATERS IN THE VICINITY OF THE CHIPROVTSI AND MARTINOVO MINES, NORTHWESTERN BULGARIA
}

\author{
Dimitrova D. ${ }^{1}$, Cholakova Z. ${ }^{2}$, Velitchkova N. ${ }^{1}$, Kotsev Ts. ${ }^{3}$, Mladenova V. ${ }^{4}$, \\ Kerestedjian T. ${ }^{1}$, and Antonov D. ${ }^{1}$ \\ ${ }^{1}$ Geological Institute, Bulgarian Academy of Sciences, 1113 Sofia, Bulgaria, \\ didi@geology.bas.bg,niaveli@geology.bas.bg,thomas@geology.bas.bg,dimia@geology.bas.bg \\ ${ }^{2}$ Sofia University, Faculty of Geology and Geography, Department of Landscape Ecology and \\ Environmental Protection, 1504 Sofia,Bulgaria, cholakova@gea.uni-sofia.bg \\ ${ }^{3}$ Institute of Geography, Bulgarian Academy of Sciences, 1113 Sofia, Bulgaria, \\ tsvetankotsev@mail.bg
}

${ }^{4}$ Sofia University, Faculty of Geology and Geography, Department of Mineralogy, Petrology and Economic Geology, 1504 Sofia, Bulgaria, vassilka@gea.uni-sofia.bg

\begin{abstract}
Chiprovtsi silver-lead and Martinovo iron mines represent the biggest mining area in Northwestern Bulgaria, which was operated till 1999. Their long-lived operation leads to proved pollution of the environment in the vicinity of the mines, especially water and soil. Seasonal monitoring of heavy metal (Cu, $\mathrm{Zn}, \mathrm{Cd}$ and $\mathrm{Pb})$ and metalloid (As and Sb) concentrations in mine, surface (river) and drinking waters was carried out during May and August 2006 to determine the level of contamination of the Chiprovska Ogosta river basin resulting from the long-lived mining activity and whether these abandoned mines continue to be potential source for water pollution. This study proves significant As concentrations in mine (up to $170 \mu \mathrm{g} / \mathrm{l}$ ) and surface waters (between 50 and $621 \mu \mathrm{g} / \mathrm{l}$ ). The presence of other heavy metals, such as $\mathrm{Cu}, \mathrm{Cd}, \mathrm{Zn}$ and $\mathrm{Pb}$, and metalloid - Sb is also recorded. Among them, $\mathrm{Pb}$ was found in considerable concentrations - up to $1456 \mu \mathrm{g} / \mathrm{l}$ during May 2006 sampling exhibiting great concentration variability between dry and wet sampling seasons. $S b$ is also determined in mine waters (up to $25 \mu \mathrm{g} / \mathrm{l}$ ), but not exists in surface and drinking waters. Drinking waters are proved to be free of heavy metals and metalloids.
\end{abstract}

Key words: Chiprovska Ogosta river basin, water pollution, arsenic, antimony, lead.

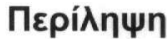

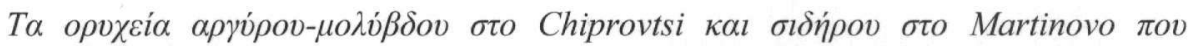

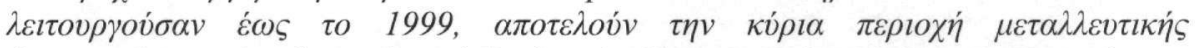

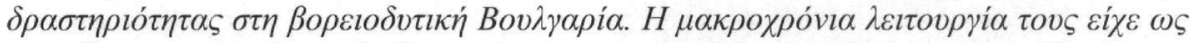

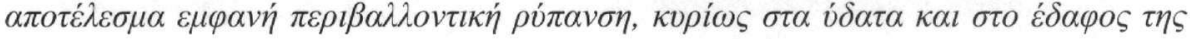




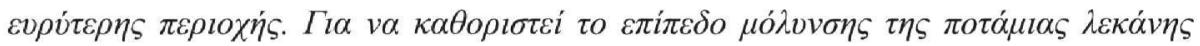

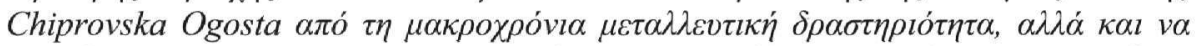

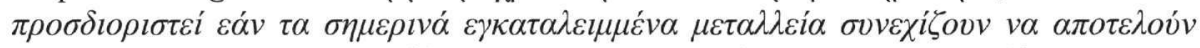

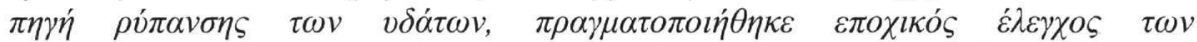

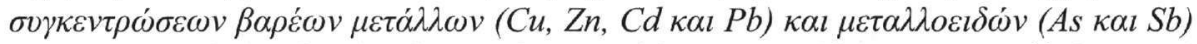

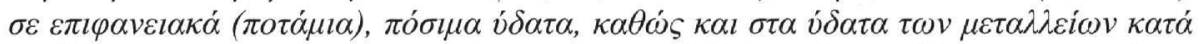

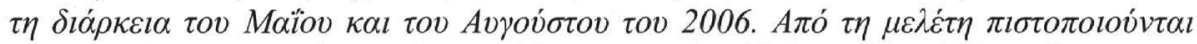

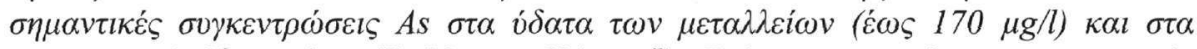

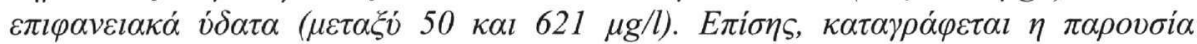

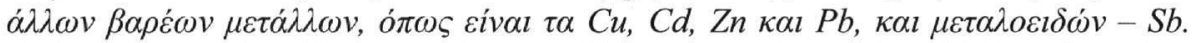

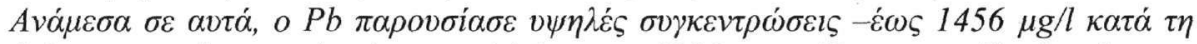

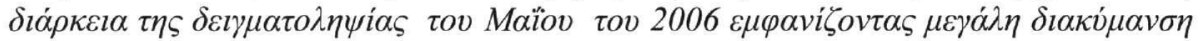

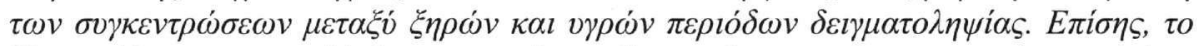

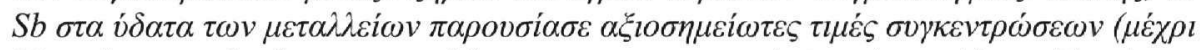

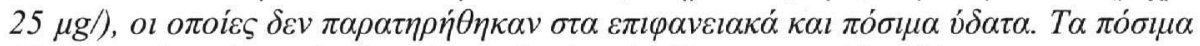

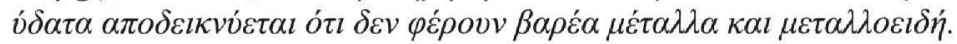

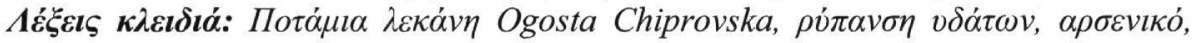
$\alpha \nu \tau \imath \mu o ́ v ı o, \mu o ́ \lambda v \beta \delta o \varsigma$.

\section{Introduction}

Mine waste tailing materials and mine waters are rich source of potentially toxic metallic and metalloid elements to the environment. Surface waters, which drain the tailing materials and wind transported fine tailing particles, create constant fluxes of toxic elements, which in turn get into river systems, soil and vegetation. Once reach the river system, pollutants can be transported to dozens of kilometers along the river downstream causing riverside area contamination far from the mining district. Although their concentrations decrease, due to dilution by surface waters, or as a result of adsorption by stream sediments, for some mobile elements, such as arsenic, the concentrations remain much higher compared to the maximum permissible level for surface waters.

The monitoring of the seasonal dynamics and concentrations of the potential pollutants in surface waters, which drain the tailings, and mine and river waters will help in prediction and prevention of possible river (irrigation) and drinking water contamination in concentrations above the guideline values. In the vicinity of the Chiprovtsi and Martinovo mines, there is a typical case of mine waters discharging into stream waters, as well as natural and clarified waters from the tailings collectors, which flow directly into Chiprovska Ogosta river system. All these significantly contribute in Chiprovska Ogosta river and riverside area pollution.

The terms "heavy metal" and "metalloid" are used in the paper to designate the elements $\mathrm{Cu}, \mathrm{Zn}$, $\mathrm{Pb}$ and $\mathrm{Cd}$, and $\mathrm{As}$ and $\mathrm{Sb}$ respectively, on the basis of their general physical and chemical properties, as it is accepted in chemistry.

\section{Geology and mining history of the Martinovo iron and Chiprovtsi silver-lead deposits}

The Martinovo iron and Chiprovtsi silver-lead deposits are hosted in the low-grade metamorphic rocks (marbles and schists) of the Diabase Phyllitoid Complex (Precambrian - Early Ordovician age) (Kalvacheva 1986, Carrigan et al. 2003). The mineralizations in both deposits comprise of Mo-W (molybdenite-scheelite), Fe (magnetite-pyrrhotite-arsenopyrite-löllingite-pyrite-siderite), $\mathrm{Ag}-\mathrm{Pb}$ (galena-tetrahedrite-Ag-Sb sulphosalts) and fluorite-barite-calcite (with minor constituent of cinnabar) (Atanassov and Pavlov 1983). Chiprovtsi and Martinovo mines are known to be exploited from Roman times, through Middle Ages, but most intensively from 1951 to 1999, when both mines ceased their activities after producing $4.79 \mathrm{Mt}$ at $1.84 \% \mathrm{~Pb}$ and $14.0 \mathrm{Mt}$ at $30.7 \% \mathrm{Fe}$ (Milev et al. 1996). Remediation activities have been carried out in the region since 2000 year, 
which covered not only the three tailing impoundments, but the numerous mine waste dumps too. At present all mine waste dumps are partially or completely remediated, except those in Rupski Dol, Lukina Padina and Dolich mine sections.

\section{Investigation objectives}

The current investigation aims to study the seasonal dynamics and distribution of the main pollutants ( $\mathrm{As}, \mathrm{Sb}, \mathrm{Pb}, \mathrm{Cu}, \mathrm{Zn}$ and $\mathrm{Cd}$ ) in mine, stream and Chiprovska Ogosta river waters, as well as their environmental state regarding remediation activities, which were carried out in the mining area since 2000 year. Seasonal alteration of main pollutants concentrations is substantial assessing the remediation effectiveness and environmental stability of the river basin.

\section{Materials and methods}

Sampling took place during both wet (high water) (May 2006) and dry seasons (low water) (August 2006) in all mine sections and at the three tailing impoundments (Mechi Dol, Chiprovtsi and Golyam Bukovets) in the vicinity of the Martinovo and Chiprovtsi mines. Samples were collected from mine waters discharging from the main adits in the Perchinki, Mali Dol, Zhazhkov Dol, Gnili Dol, Velin Dol, Lukina Padina and Dolich mine sections and from stream waters in the Yavorov Dol, Sinya Voda and Rupski Dol mine sections, as well as samples from particular points along the Golyam Bukovets river and Chiprovska Ogosta river downstream. Two samples of drinking water were collected from public fountains in the village of Zhelezna (Fig. 1). Sample locations were recorded with a handheld Garmin-GPS device. Physico-chemical parameters of waters ( $\mathrm{pH}, \mathrm{T}, \mathrm{TDS}$ and EC) were measured in situ with Combo HANNA portable equipment ( $\mathrm{pH}$-meter and conductivity meter). All water samples were collected according to the international water sampling guidelines (WHO, 1996), ISO 5667-3:1994 and ISO 566714:1998. Each $100 \mathrm{ml}$ water sample was collected in polyethylene bottle with $50 \mathrm{ml}$ syringe; in situ filtrated through $0.45 \mu \mathrm{m}$ pore diameter membrane filters, and acidified separately with supra pure acids: $5 \mathrm{ml} \mathrm{HCl}$ (for $\mathrm{As}$ and $\mathrm{Sb}$ ), and $1 \mathrm{ml} \mathrm{HNO}$ (for $\mathrm{Pb}, \mathrm{Cu}, \mathrm{Zn}$ and $\mathrm{Cd}$ ). The concentrations of $\mathrm{As}, \mathrm{Sb}, \mathrm{Pb}, \mathrm{Cu}, \mathrm{Zn}$ and $\mathrm{Cd}$ in the samples were determined by inductively coupled plasma atomic emission spectroscopy using HR-ICP-AES Jobin Yvon Ultima 2 at the Geological Institute, BAS and ICP-AES equipment at the geochemistry laboratory, University of Mining and Geology, Sofia in agreement with ISO 11885:1996(E).

\section{Results and discussion}

\subsection{Seasonal concentration variations of heavy metals and metalloids in mine waters}

The measured in situ physico-chemical parameters of mine waters slightly differ during May 2006 and August 2006, but distinct increase of the measured temperature, total dissolved solids (TDS) and conductivity is observed during dry season for all sampled waters. Seasonal monitoring did not ascertain regular seasonal correlation of $\mathrm{pH}$ values for all mine waters. $\mathrm{pH}$ values range from 7.40 (Mali Dol, May 2006) up to 8.76 (Dolich, August 2006), but remain almost equal to neutralnear neutral $\mathrm{pH}$, due to the carbonate-buffering by the host rocks (siderite marbles). This also prevents acid mine drainage (AMD) generation discharge from the mines and retains the sulphides dissolution ability low. The estimated total concentrations of heavy metals and metalloids in the waters collected in May 2006 are significantly higher than those collected in August 2006, except for the arsenic contents, which have reverse correlation and are relatively higher during August 2006 sampling (Table 1 ). 


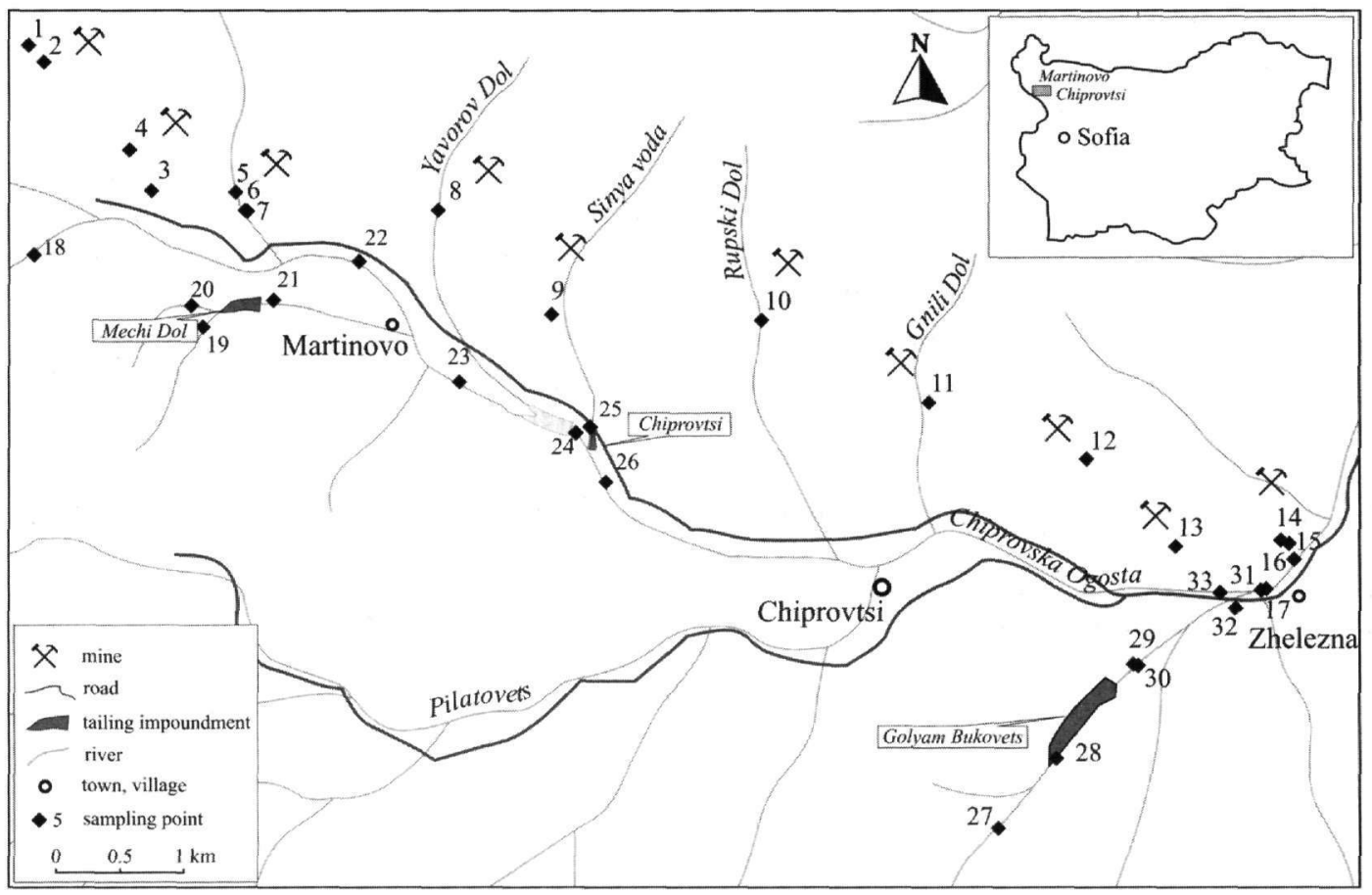

Figure 1 - Location of the Chiprovska Ogosta river basin, showing the mining area, tailing impoundments and sampling points

The observed concentrations of each element show apparent correlation with the particular mineralization in each mine section. The highest arsenic concentrations are determined in the mine waters from Perchinki, Mali Dol and Zhazhkov Dol mine sections, where the ore is strongly enriched with arsenopyrite and löllingite. Similarly to this, the highest lead and antimony concentrations determined in waters from Sinya Voda, Gnili Dol, Lukina Padina and Dolich mine sections are related to the galena-tetrahedrite containing ore in Chiprovtsi mine.

Previous mine water investigations carried out by Kotsev $(2001,2003)$, when compared to this study, show considerable decrease in the lead, zinc, copper, cadmium and arsenic concentrations in mine waters at present, probably resulting from the cessation of mining activity.

However, the lack of data about antimony concentration in mine waters, especially from Lukina Padina and Dolich mine sections, did not allow us to correlate the obtained data in this study to previous investigations. Antimony was not examined in mine waters in Bulgaria so far, because of its insignificant quantity in the processed ores. Taking into account its presence in the mined ores from Chiprovtsi mine and its behavior and toxicity to the environment, we decided to examine its concentration in mine waters and explore whether it could be, or is a potential pollutant of the waters in the study area. The determined total antimony concentration in 5 from 15 mine waters samples does not exceed $25 \mu \mathrm{g} / \mathrm{l}$, which is slightly above the maximum permissible values (MOEW 2001) and WHO guideline values (WHO 2004) (Tables 1, 2) for surface water. Actually, we did not find any data about antimony concentrations in mine, surface and drinking waters in Bulgaria at all. According to Alderton et al. (2005) the highest dissolved Sb concentrations occur in alkaline waters ( $\mathrm{pH} 7-9)$ in contrast with As and are related not only to the mineralization type, but to $\mathrm{pH}$. Antimony forms oxyanions and the most common is $\mathrm{Sb}(\mathrm{OH})_{6}{ }^{-}$and the solubility of this species is higher in neutral to alkaline conditions (Longmuir 1997). Similarly to other heavy metals and arsenic, antimony can be adsorbed by Fe oxides and hydroxides, and thereby disappears from the water. The fact that antimony was not determined in surface waters is an evidence that it was adsorbed very close to the adits, probably in soil, or in bed sediments inside 
the adits. The determined $\mathrm{Sb}$ concentrations are considerably lower than those measured in Macedonia (Krstov Dol mine) (Alderton et al. 2005), which reached $100.3 \mu \mathrm{g} / \mathrm{l}$. However, the results of August 2006 sampling compared to the September 2005 reported elsewhere (Dimitrova et al. 2006) show substantial difference between both dry seasons, caused probably by the higher humidity and average annual rainfall estimated for the 2005 year. The total heavy metal concentrations including $\mathrm{Cu}, \mathrm{Cd}, \mathrm{Zn}$ and $\mathrm{Pb}$ determined in 2006 year dry season waters are actually below the detection limits of the used ICP-AES method. These results have positive correlation with those derived in 2005 although they are much lower, as the 2005 dry season was unusually wet. The increased ionic concentration represented by the higher values of TDS and EC probably result in much higher level of precipitation processes during dry season, which in turn can explain the lack of heavy metals in the waters. They were probably included in the precipitated iron hydroxides.

Table 1 - Seasonal physico-chemical parameters and estimated heavy metal and metalloid concentrations in mine waters

\begin{tabular}{|c|c|c|c|c|c|c|c|c|c|c|c|}
\hline № & $\begin{array}{l}\text { Sampling place (mine } \\
\text { section, level) }\end{array}$ & pH & $\begin{array}{c}\text { TDS } \\
(\mathbf{p p m})\end{array}$ & $\begin{array}{c}\mathbf{T} \\
\left({ }^{\circ} \mathbf{C}\right)\end{array}$ & $\begin{array}{c}\mathrm{EC} \\
\left(\mu \mathrm{Scm}^{-1}\right)\end{array}$ & $\begin{array}{c}\mathrm{Cu} \\
(\mu \mathrm{g} / \mathrm{l})\end{array}$ & $\begin{array}{c}\mathrm{Zn} \\
(\mu \mathrm{g} / \mathrm{l})\end{array}$ & $\begin{array}{c}\text { Cd } \\
(\mu g / l)\end{array}$ & $\begin{array}{c}\mathrm{Pb} \\
(\mu \mathrm{g} / \mathrm{l})\end{array}$ & $\begin{array}{c}\text { As } \\
(\mu \mathrm{g} / \mathrm{l})\end{array}$ & $\begin{array}{c}\text { Sb } \\
(\mu \mathrm{g} / \mathrm{l})\end{array}$ \\
\hline \multirow{2}{*}{1.} & \multirow{2}{*}{ Perchinki, 940, adit } & 7.88 & 140 & 9.0 & 289 & 14 & 8 & 9 & 275 & 119 & - \\
\hline & & 7.53 & 210 & 8.6 & 445 & - & - & - & - & 149 & - \\
\hline \multirow{2}{*}{2.} & \multirow{2}{*}{ Perchinki, 900, adit } & 7.59 & 142 & 6.6 & 303 & 11 & 9 & 9 & 265 & 71 & - \\
\hline & & 7.73 & 226 & 7.5 & 451 & - & - & - & - & 77 & - \\
\hline \multirow{2}{*}{3.} & \multirow{2}{*}{ Mali Dol, 810, adit } & 7.40 & 154 & 8.4 & 315 & 156 & 332 & - & - & 114 & 4 \\
\hline & & 7.80 & 210 & 9.8 & 420 & - & & - & - & 147 & - \\
\hline \multirow{2}{*}{4.} & \multirow{2}{*}{ Mali Dol, 850, adit } & 7.66 & 160 & 8.4 & 315 & 68 & 12 & 4 & 34 & 140 & - \\
\hline & & 7.83 & 242 & 11.4 & 481 & 24 & 19 & - & - & 144 & - \\
\hline \multirow{2}{*}{5.} & \multirow{2}{*}{ Zhazhkov Dol, 760, adit } & 8.17 & 225 & 7.2 & 450 & - & - & - & - & - & - \\
\hline & & 8.00 & 287 & 9.0 & 567 & - & - & - & - & 170 & - \\
\hline \multirow{2}{*}{6.} & \multirow{2}{*}{ Zhazhkov Dol, ore-chute } & 8.06 & 230 & 10.0 & 480 & 36 & 13 & 31 & 484 & 121 & - \\
\hline & & 8.18 & 288 & 11.2 & 562 & - & - & - & - & 168 & - \\
\hline \multirow{2}{*}{7.} & \multirow{2}{*}{$\begin{array}{l}\text { Zhazhkov Dol, } 740 \text {, } \\
\text { drainage water }\end{array}$} & 7.69 & - & 16.1 & 200 & - & 1 & 5 & 66 & 12 & - \\
\hline & & - & - & - & - & - & - & - & - & - & - \\
\hline \multirow{2}{*}{9.} & \multirow{2}{*}{ Sinya Voda, 620 , adit } & 8.54 & 238 & 8.9 & 649 & 27 & 15 & 8 & 171 & 31 & - \\
\hline & & 8.38 & 388 & 7.5 & 780 & - & - & - & - & 23 & - \\
\hline \multirow{2}{*}{11.} & \multirow{2}{*}{$\begin{array}{l}\text { Gnili Dol, 570, lake in front } \\
\text { the adit }\end{array}$} & 8.29 & 148 & 14.7 & 300 & 17 & 7 & 10 & 277 & 9 & 17 \\
\hline & & 8.49 & 175 & 17.5 & 350 & - & - & - & - & - & - \\
\hline \multirow{2}{*}{12.} & \multirow{2}{*}{ Velin Dol, 545, adit } & 7.90 & 202 & 11.6 & 405 & 14 & 8 & 11 & 264 & 7 & - \\
\hline & & 7.94 & 202 & 12.6 & 416 & - & - & - & - & - & - \\
\hline \multirow{2}{*}{13.} & \multirow{2}{*}{ Lukina Padina, 495, adit } & 8.47 & 275 & 9.4 & 541 & 19 & 25 & 47 & 1456 & 34 & 18 \\
\hline & & 8.26 & 343 & 12.3 & 680 & - & - & - & - & 20 & - \\
\hline \multirow{2}{*}{14.} & \multirow{2}{*}{ Dolich, 415, adit } & 8.05 & 240 & 11.5 & 492 & 11 & 10 & 11 & 431 & 8 & 25 \\
\hline & & 8.06 & 305 & 13.0 & 605 & - & - & - & - & 13 & - \\
\hline \multirow{2}{*}{15.} & \multirow{2}{*}{ Dolich, 395, drainage water } & 8.30 & 237 & 14.0 & 474 & 8 & 7 & 8 & 259 & 7 & 21 \\
\hline & & 8.76 & 265 & 27.1 & 534 & - & - & - & - & - & - \\
\hline
\end{tabular}

Values for each sampling point on first line - May 2006, second line - August 2006; - Element not found at detection limits: $\mathrm{Cu}-5 \mu \mathrm{g} / \mathrm{l}, \mathrm{Zn}-2 \mu \mathrm{g} / \mathrm{l}, \mathrm{Pb}$ and $\mathrm{Sb}-10 \mu \mathrm{g} / \mathrm{l}, \mathrm{As}-7 \mu \mathrm{g} / \mathrm{l}$;

Abbreviations: $\mathrm{pH}$ - measure of the acidity and alkalinity, TDS - total dissolved solids, $\mathrm{T}$ temperature, EC - conductivity 
Lead concentration variations during May sampling vary between $34 \mu \mathrm{g} / 1$ (Mali Dol) and 1456 $\mu \mathrm{g} / \mathrm{l}$ (Lukina Padina) to absolute absence in all samples during August, which most probably is controlled by the entire water ionic composition during the wet and dry seasons. Of particular significance are the $\mathrm{SO}_{4}{ }^{2-}$ and $\mathrm{HCO}_{3}{ }^{-}$concentrations, which in principle control the lead content in mine waters (Blowes and Ptacek 1994). Most likely, lead was included in the bed sediments inside the adits.

Table 2 - WHO (World Health Organization) guideline values and MOEW (Ministry of Environment and Water) maximum permissible values (MPV) of $\mathrm{Cu}, \mathrm{Cd}, \mathrm{Zn}, \mathrm{Pb}$, As and $\mathrm{Sb}$ for drinking and surface water

\begin{tabular}{|l|c|c|c|c|c|c|c|c|c|}
\hline \multicolumn{1}{|c|}{ Organization, guideline values } & $\mathbf{p H}$ & $\begin{array}{c}\mathbf{T} \\
\left({ }^{\circ} \mathbf{C}\right)\end{array}$ & $\begin{array}{c}\mathbf{E C} \\
\left(\mu \mathbf{S c m}^{-1}\right)\end{array}$ & $\begin{array}{c}\mathbf{C u} \\
(\mu \mathrm{g} / \mathbf{l})\end{array}$ & $\begin{array}{c}\mathbf{Z n} \\
(\mu \mathrm{g} / \mathbf{l})\end{array}$ & $\begin{array}{c}\mathbf{C d} \\
(\mu \mathrm{g} / \mathbf{l})\end{array}$ & $\begin{array}{c}\mathbf{P b} \\
(\mu \mathrm{g} / \mathbf{l})\end{array}$ & $\begin{array}{c}\mathbf{A s} \\
(\mu \mathrm{g} / \mathbf{l})\end{array}$ & $\begin{array}{c}\mathbf{S b} \\
(\mu \mathrm{g} / \mathbf{l})\end{array}$ \\
\hline $\begin{array}{l}\text { MOEW (1986), MPV, surface water, } 2^{\text {nd }} \\
\text { category }\end{array}$ & $6.0-8.5$ & 20.0 & 1300 & 100 & 5000 & 100 & 50 & 50 & - \\
\hline MOEW (2000), MPV, waste water & $6.0-9.0$ & - & - & 500 & 2000 & 100 & 200 & 100 & - \\
\hline MOEW (2001), MPV, drinking water & $6.5-9.5$ & 20.0 & 2000 & 2000 & 5000 & 5 & 10 & 10 & 5 \\
\hline $\begin{array}{l}\text { WHO (2004), guideline values, drinking } \\
\text { water }\end{array}$ & $<8.0$ & - & - & 2000 & 3000 & 3 & 10 & 10 & 20 \\
\hline
\end{tabular}

On the contrary, arsenic concentrations remain high and almost constant during the monitored seasons including September 2005 (Dimitrova et al. 2006). Some authors consider arsenopyrite as relatively stable mineral under oxidizing conditions, near neutral $\mathrm{pH}$ and comparatively high Eh (Jambor 1994). However, there are numerous papers concerning oxidation processes of arsenopyrite and pyrite. Through oxidation in fresh air, water, or even mine waters, coatings of Fe (III) oxyhydroxides up to $50 \AA$ thick are formed on the minerals surfaces (Nesbitt and Muir, 1998). These coatings commonly include hematite, goethite, and an overlayer composed also by arsenate $\left(\mathrm{AsO}[\mathrm{OH}]_{3}\right)$, or $\mathrm{FeAsO}_{4}$, and even the reduced arsenic species $\left(\mathrm{As}[\mathrm{OH}]_{3}\right)$, or $\mathrm{FeAsO}_{3}$. These coatings did not offer protection of continuous leaching of arsenic from the bulk. Thus, arsenopyrite still dissolves in water through oxidation and leaching processes and its concentration reaches up to 200-300 $\mu \mathrm{g} / \mathrm{l}$. Arsenopyrite decomposes following the simplified reaction: FeAsS + $7 \mathrm{H}_{2} \mathrm{O}=\mathrm{Fe}^{2+}(\mathrm{aq})+\mathrm{H}_{3} \mathrm{AsO}_{3}(\mathrm{aq})+11 \mathrm{H}^{+}+11 \mathrm{e}^{-}+\mathrm{SO}_{4}{ }^{2-}$. As far as dissolution is a function of the temperature, substance chemistry, $\mathrm{pH}$ and $\mathrm{Eh}$, could be assumed, that at $8-10{ }^{\circ} \mathrm{C}$ and $\mathrm{pH}-7-8$ of the water in the underground workings, the arsenopyrite dissolution would be lower than that calculated for $25^{\circ} \mathrm{C}$ by Craw et al. (2003). According to this study, the dissolution is probably enough to produce about $100-170 \mu \mathrm{g} / 1$ dissolved $\mathrm{As}^{3+}(\mathrm{aq})+\mathrm{As}^{5+}(\mathrm{aq})$ in the waters, as it was determined in mine waters from Perchinki, Mali Dol and Zhazhkov Dol mine sections.

\subsection{Seasonal concentration variations of heavy metals and metalloids in stream, river and drinking waters}

Chiprovska Ogosta river has a relatively small and intermittent flow. The average measured quantities at Chiprovtsi station are as follows: maximum values during April - May $-1.9 \mathrm{~m}^{3} / \mathrm{s}$ and minimum during August $-0.2 \mathrm{~m}^{3} / \mathrm{s}$.

The concentrations of the dissolved heavy metals and metalloids decrease during the wet season reaching values below the detection limits of the ICP-AES method, as being diluted by the water. This is not valid for the arsenic concentrations, which vary between $<10$ and $297 \mu \mathrm{g} / \mathrm{l}$. The highest arsenic concentration $(297 \mu \mathrm{g} / \mathrm{l})$ is determined at the clarified waters collector outlet of the Golyam Bukovets tailing impoundment and it appears to be three times higher than the permissible value for hazardous and harmful substances $(100 \mu \mathrm{g} / 1)$ in effluent waste waters discharged into the river systems (Table 2, MOEW 2000). The arsenic values determined in the natural waters collector outlet of the Mechi Dol tailing impoundment nearly reach the permissible limit. The Chiprovska Ogosta river basin is signed to a second water stream category in Bulgaria (MOEW 1986), i.e. 
the surface waters are not applicable for drinking water-supply, but are suitable for irrigation, fish farming, watering and for industrial purposes. As it is shown in Table 3 and Figure 2, the arsenic concentrations estimated for all sampling points along the river downstream during wet season exceed the guideline value for $2^{\text {nd }}$ surface waters category nearly 2.7 times. Especially noticeable is the concentration increase, found out in the river waters after entering the town of Chiprovtsi, which is probably due to the flow from the left tributaries Rupski Dol and Gnili Dol, which pass through the mining areas. It apparently decreases at the Montana artificial lake near Gorno Tserovene village, reaching levels below the guideline values for the second surface waters category (44 $\mu \mathrm{g} / \mathrm{l})$ (Fig. 2).

The self-purification processes are considerably reduced through the dry season (August 2006) and arsenic concentrations determined in all sampling points exceed the guideline values from 1.1 to 3.46 times. The highest concentration estimated in the river waters is at the point near Zhelezna village.

The three tailing impoundments in the mines vicinity significantly contribute in river waters pollution, particularly regarding arsenic concentration. Among them, the natural waters collector of Mechi Dol tailing impoundment releases the highest contents of dissolved arsenic $-621 \mu \mathrm{m} / \mathrm{l}$, which 6 times exceeds the guideline values for waste waters. Nevertheless, arsenic rather rapidly precipitates or is adsorbed by the channel sediments not very far from the outlet - at about $2 \mathrm{~km}$, as the concentration decreases to $85 \mu \mathrm{m} / 1$ before flowing into Martinovo artificial lake, as it is shown on Figure 3. On the other hand, Chiprovtsi tailing impoundment directly contributes in river pollution by metal remobilization processes caused by its immediate riverside location. In addition, Sinya Voda stream, which rinses the mine waste material near the adit, increases the arsenic concentration in Chiprovska Ogosta river up to 3 times above the guideline values. Most of the determined arsenic concentrations in surface waters result from oxidation and remobilization processes occur in the tailing impoundments, which contain significant amounts of arsenopyrite, pyrite and other sulphides (Vesselinov et al. 1996).

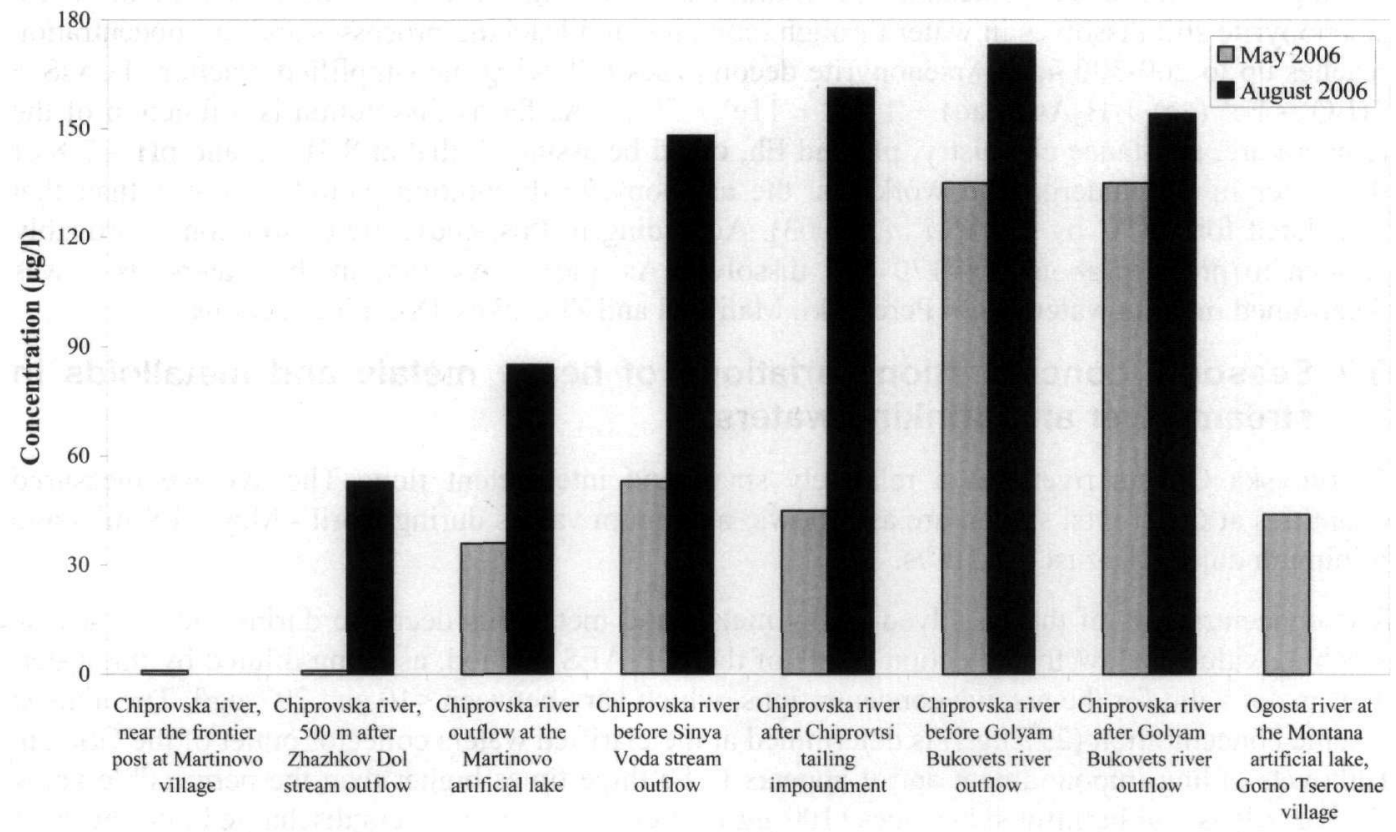

Figure 2 - Total arsenic concentrations determined at certain sampling points along the Chiprovska Ogosta downstream during May and August 2006 


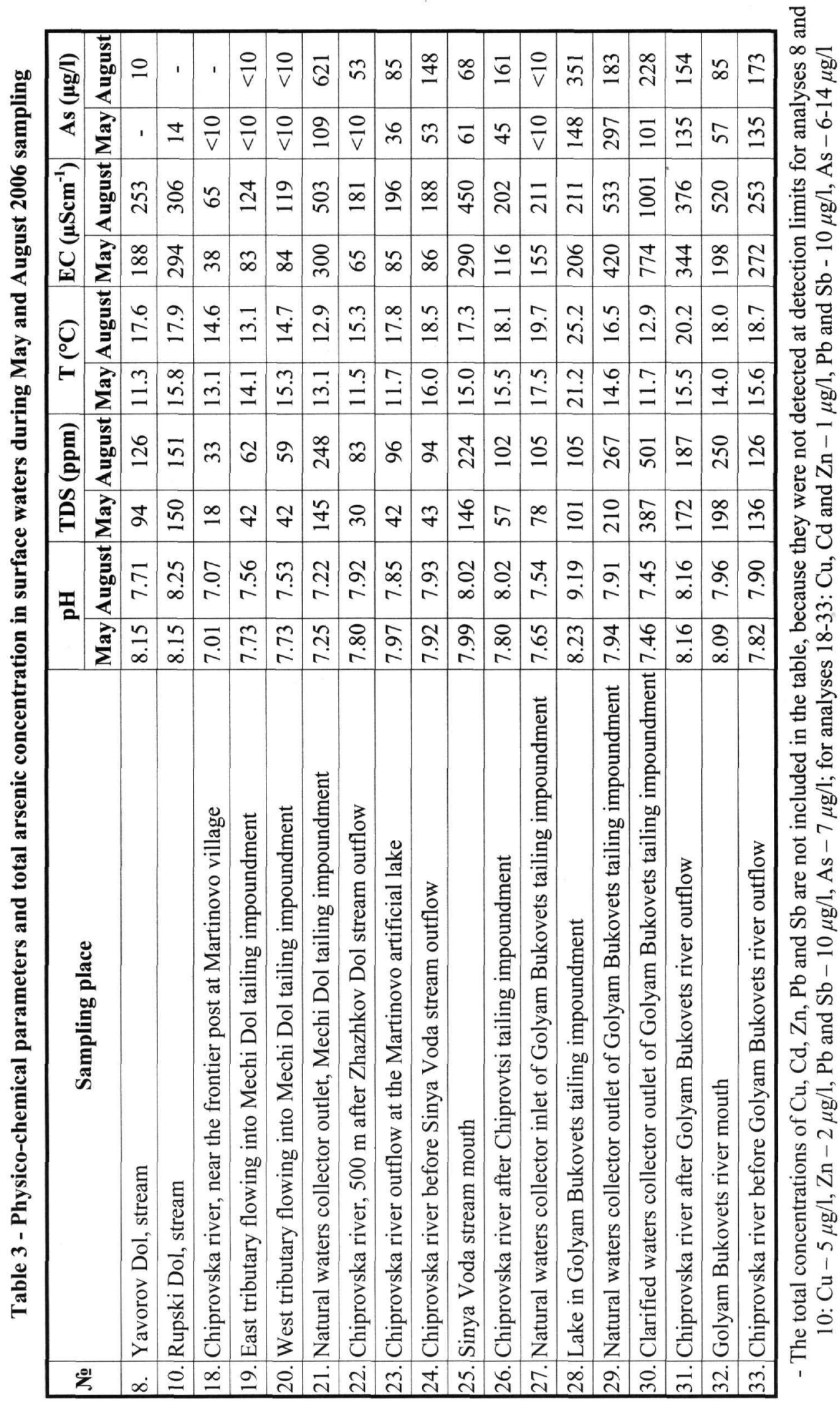




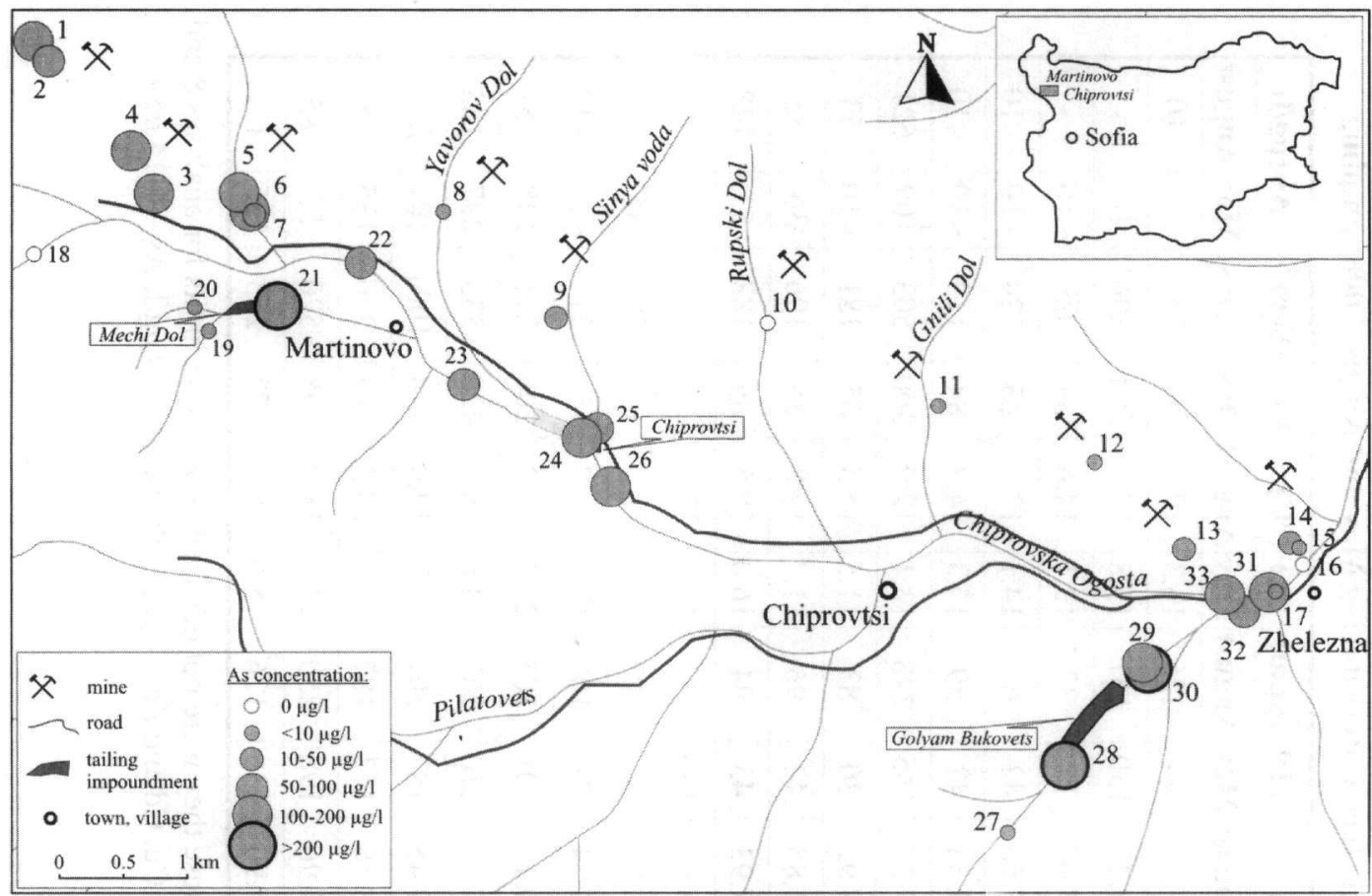

Figure 3 - A view of the studied area showing arsenic levels $(\mu \mathrm{g} / \mathrm{l})$ in mine, surface and drinking water

In comparison to previous studies carried out during August 2005 (Cholakova et al. 2006), an obvious trend of arsenic concentration elevation is outlined in Chiprovska Ogosta river on leaving the town of Chiprovtsi. However, they cannot be linked to concrete impact of the tailing impoundments and mining workings. Thus, a detailed sampling along the river downstream, and all left tributaries between Chiprovtsi tailing impoundment and Golyam Bukovets river mouth has to be done, including total ionic composition monitoring as well.

The investigation of the drinking water samples did not show any concentrations of heavy metals and arsenic (Table 4), i.e. drinking water from the public fountains in Zhelezna village is absolutely harmless to humans. Further monitoring is still needed assuring our statement.

Table 4 - Physico-chemical parameters and total $\mathrm{Cu}$ and $\mathrm{Zn}$ concentration in drinking waters during May 2006 sampling

\begin{tabular}{|c|c|c|c|c|c|c|c|c|c|c|c|}
\hline \multirow{2}{*}{ № } & \multirow{2}{*}{ Sampling place } & \multicolumn{2}{|r|}{ pH } & \multicolumn{2}{|c|}{ TDS (ppm) } & \multicolumn{2}{|c|}{$\mathrm{T}\left({ }^{\circ} \mathrm{C}\right)$} & \multicolumn{2}{|c|}{$\mathrm{EC}\left(\mu \mathrm{Scm}^{-1}\right)$} & \multirow{2}{*}{$\begin{array}{c}\mathrm{Cu} \\
(\mu \mathrm{g} / \mathrm{l})\end{array}$} & \multirow{2}{*}{$\begin{array}{c}\begin{array}{c}\mathrm{Zn} \\
(\mu \mathrm{g} / \mathrm{l})\end{array} \\
\text { May* }\end{array}$} \\
\hline & & May & August & May & August & May & August & May & August & & \\
\hline 16. & $\begin{array}{l}\text { Zhelezna village, near } \\
\text { Dolich mine section, } \\
\text { drinking water }\end{array}$ & - & 7.79 & - & 283 & - & 16.8 & - & 578 & - & - \\
\hline 17. & $\begin{array}{l}\text { Zhelezna village, } \\
\text { drinking water }\end{array}$ & 7.20 & 7.06 & 105 & 140 & 10.6 & 17.6 & 212 & 284 & 4 & 6 \\
\hline
\end{tabular}

* - $\mathrm{As}, \mathrm{Sb}, \mathrm{Pb}, \mathrm{Cd}$ were not detected during the monitoring, while $\mathrm{Cu}$ and $\mathrm{Zn}$ were detected only during May 2006 sampling 


\section{Conclusions}

The measured physico-chemical parameters of mine and surface waters during dry season also show high conductivity and TDS values. The $\mathrm{pH}$ values in all sampled waters remain near neutral during the monitored period showing slight elevation during dry season. This fact, resulting from the sufficient amount of $\mathrm{CO}^{2^{-}} \mathrm{HCO}_{3}{ }^{2} \mathrm{OH}^{-}$in the water, which come from the host rocks (siderite marbles), confirms that acid mine drainage from the adits and tailing impoundments could not be expected and there is no need of further activities to limit such effect.

The most hazardous element in mine and surface waters is arsenic. Its concentrations in mine waters show insignificant variability between wet and dry seasons, but remain almost equal. The highest As concentrations (up to $170 \mu \mathrm{g} / \mathrm{l}$ ) in mine waters are observed in the western part of the mining area (Perchinki, Mali Dol and Zhazhkov Dol mine sections). In surface waters arsenic concentration is ranging between 60 and $80 \mu \mathrm{g} / \mathrm{l}$, but abruptly increases above $170 \mu \mathrm{g} / \mathrm{l}$ instantly after each tailing impoundment water collector outflow to the river. The highest arsenic concentrations (from 228 to $621 \mu \mathrm{g} / \mathrm{l}$ ) are observed during dry season, resulting from the low flow in the whole river system. The determined high arsenic concentrations in river waters (several times exceeding the guideline values) categorize them as unsuitable for irrigation.

The other heavy metals and antimony are not found in surface waters in concentrations above the guideline values and do not pose a threat to the waters. In mine waters, these metals occur in much higher values, especially lead, which concentrations vary between $1456 \mu \mathrm{g} / \mathrm{l}$ and $<10 \mu \mathrm{g} / \mathrm{l}$ during wet and dry seasons, respectively. As lead concentration in water very much depends on the anionic composition, particularly $\mathrm{SO}_{4}{ }^{2-}$ and $\mathrm{HCO}_{3}{ }^{-}$, during dry season it is easily adsorbed by the channel sediments and soil, or precipitates as sulphate (anglesite). Thus, it is considered as a serious contaminant to soil and vegetation.

This study did not record any contamination in drinking water, even with arsenic, thus using drinking water from the public fountains in Zhelezna village do not pose a threat to the population.

The concentrations of $\mathrm{As}, \mathrm{Cu}, \mathrm{Cd}$ and $\mathrm{Pb}$ are significantly decreased in comparison to these measured during mining (Kotsev 2001, 2003), but still remain very high regarding the guideline values. This means, that sulphide oxidation and metal remobilization processes are still running in the underground workings and tailing impoundments and they remain a constant source of heavy metal and metalloid contamination mainly for the water bodies and riverside agricultural land. Thus we consider, that the remediation activities carried out in the mining area are not very successful and a seasonal monitoring of the pollutants concentration for several years will show in what extent a pollution of waters can be expected in the area and what preventive measures have to be taken to restrict such contaminations.

\section{Acknowledgments}

This study is supported financially by the National Science Foundation grants NZ-MU-1507/05 and VU-NZ-04/05.

\section{References}

Alderton, D.H.M., Serafimovski, T., Mullen, B., Fairall, K., and James, S., 2005. The chemistry of waters associated with metal mining in Macedonia, Mine Water and the Environment, 24, 139-149.

Atanassov, V., and Pavlov, I., 1983. Notes about mineralogy and paragenetic zoning of minerals deposits in Chiprovtsi ore region, Ann. Ecol. Sup. Min. Geol., 28, 2 (1981-1982), 159-178. (in Bulgarian) 
Blowes, D., and Ptacek. C., 1994. Acid-neutralization mechanisms in inactive mine tailings. In J. Jambor and D. Blowes (eds) Short Course Handbook on Environmental Geochemistry of Sulphide Mine Wastes., Mineralogical Association of Canada, Waterloo, Ontario, 438p.

Carrigan, C.W., Mukasa, S.B., Haydoutov, I., and Kolcheva, K., 2003. Ion microprobe U-Pb zircon ages of pre-Alpine rocks in the Balkan, Sredna Gora and Rhodope Terranes of Bulgaria: Constraints on Neoproterozoic and Variscan tectonic evolution, J. Czech Geol. Soc., $48,32-33$.

Carrigan, C.W., Mukasa, S.B., Haydoutov, I., and Kolcheva, K., 2005. Age of Variscan magmatism from the Balkan sector of the orogen, Central Bulgaria, Lithos, 82, 125-147.

Cholakova, Z., Kotsev, T., Mladenova, V., Dimitrova, D., and Georgieva, I., 2006. Assessment of heavy metal and arsenic concentrations in the waters of Chiprovska river catchment. In Proceedings of International Scientific Conference "Global changes and regional challenges", Sofia University, Faculty of Geology and Geography, Sofia ,28-29 April 2006. (in press)

Craw, D., Falconer, D., and Youngson, J., 2003. Environmental arsenopyrite stability and dissolution: theory, experiment, and field observations, Chem. Geol., 199, 71-82.

Dimitrova, D., Velitchkova, N., Kotsev, Ts., Antonov, D., and Cholakova, Z., 2006. Heavy metals and metalloids content assessment in mine waters from the Martinovo and Chiprovtsi mines, Northwestern Bulgaria. In Proceedings of Annual Conference of Bulgarian Geological Soviety “Geonauki 2006”, Sofia, 30.11.-01.12., Abstracts. (in press)

ISO 11885:1996. Water quality - Determination of 33 elements by inductively coupled plasma atomic emission spectroscopy.

ISO 5667-3:1994. Water quality - Sampling - Part 3: Guidance on the preservation and handling of samples.

ISO 5667-14:1998. Water quality - Sampling - Part 14: Guidance on quality assurance of environmental water sampling and handling.

Jambor, J., 1994. Mineralogy of sulphide-rich tailings and their oxidation products. In J. Jambor and D. Blowes. (eds) Short Course Handbook on Environmental Geochemistry of Sulphide Mine Wastes., Mineralogical Association of Canada, Waterloo, Ontario, 438p.

Kalvacheva, R., 1986. Acritarch stratigraphy of the Ordovician System in Bulgaria. In IGCP project No 5 "Correlation of Prevariskan and Variskan events in the Alpine Mediterranean Mountain belts", Sardinia, Abstracts, 38-43pp.

Kotsev, Ts., 2001. Contemporary heavy metal and arsenic river pollution in the "Ogosta" reservoir drainage basin after the end of the mining activities. In Balkan scientific-applied conference "Natural potential and sustainable development of the mountain regions", 2001, Vratsa, Abstracts, 415-426pp. (in Bulgarian)

Kotsev, Ts., 2003. Landscape and geochemical variations in "Ogosta" reservoir drainage basin induced by the mining activity, PhD Thesis, Sofia, 2003, 234pp. (in Bulgarian)

Longmuir, D. 1997. Aqueous Environmental Geochemistry. Prentice-Hall, 576 p.

Milev, V., Stanev, V., and Ivanov, V., 1996. The Extracted Ores in Bulgaria during 1878-1995Statistical Reference Book, Sofia, Zemya 93, 196pp. (in Bulgarian)

Nesbitt, H.W., and Muir, I.J., 1998. Oxidation states and speciation of secondary products on pyrite and arsenopyrite reacted with mine waste waters and air, Mineral. Petrol.,62, 123144. 
MOEW (Ministry of Environment and Water), 1986. Regulation № 7 of 8 August 1986 on the Quality of Flowing Surface Waters. State Gazette, 96/1986. (in Bulgarian)

MOEW (Ministry of Environment and Water), 2000. Regulation № 6 of 9 November 2000 on the Limit Values for Admissible Contents of Dangerous and Harmful Substances in the Waste Water Discharged in the Water Bodies. Promulgated, State Gazette № 97/28.11.2000.

MOEW (Ministry of Environment and Water), 2001. Regulation №. 9 of 16 March 2001 on the Quality of Water Intended for Human Consumption. State Gazette, № 30/28 May 2001.

Vesselinov, I., Kolarova, V., Hadjiev, A., Hrischeva, E., and Kerestedjian, T., 1996. Mineralogical and geochemical characteristics of two tailings ponds of the Martinovo and Chiprovtsi ore dressing plants, Geochem. Mineral. Petrol. 31, 89-102. (in Bulgarian)

WHO (World Health Organization), 2004. Guidelines for Drinking Water Quality, Vol. 1: Recommendations. $3^{\text {rd }}$ edition, World Health Orgainzation, Geneva, 515pp.

WHO (World Health Organization) 1996. Water Quality Assessments - A Guide to Use of Biota, Sediments and Water in Environmental Monitoring - Second Edition, University Press, Cambridge, 609pp. 